\title{
Oral history as a tool of legal analysis: women in the margins of Israeli society
}

\author{
SHIMRIT LEE \\ SOAS, University of London
}

\begin{abstract}
$\underline{\text { Abstract }}$
Researchers in the field of legal consciousness have traditionally relied on surveys, ethnographies, or in-depth interviews to gange the ways in which individuals engage, avoid, or resist the law. This paper explores how oral history is able to enrich the study of legal consciousness in ways inaccessible to other methodologies. Oral history offers an intertemporal perspective, allowing researchers to trace the development and evolution of legal attitudes and interactions over time. To illustrate the unique function of oral history, I examine the oral history narratives of three Palestinian-Israeli women as they relate their experience with the law over the course of their lifetime. I suggest that combining the oral history technique with the more targeted approach of in-depth interviewing can most aptly capture individual legal consciousness. Research through oral history can further be used in the field of critical legal theory by drawing attention to collective historical grievances of marginalised groups.
\end{abstract}

\section{Introduction}

Tn the 1997 case of Delgamuukw v British Columbia, ${ }^{1}$ the Canadian Supreme Court ruled that 1 oral history could serve as evidence in cases involving aboriginal land claims. The First Nations of Gitksan and Wet'suwet'en used oral history - their primary form of historical documentation - to claim territorial jurisdiction. ${ }^{2}$ The court acknowledged the difficulties in reliability posed by oral history, yet oral sources were ultimately found to be on equal footing with other forms of historical written documentation. ${ }^{3}$ This expansion of evidentiary laws allowed indigenous historical knowledge to emerge from the confines of traditional legal discourse.

This paper seeks to reassert the power of oral history by examining how it can be used as an effective tool for qualitative socio-legal analysis. Specifically, I demonstrate how oral history can trace the development of individual legal consciousness over time, which can aptly complement other qualitative methods. The study draws from oral narratives of Palestinian women in Israel to demonstrate how oral history can contribute an intertemporal perspective to the study of legal consciousness and can be used as a tool for

1 Delgamunkw v British Columbia [1997] 3 SCR 1010.

2 M Sparke, 'A Map that Roared' (1998) 88(3) Annals of the Association of American Geographers 2.

3 Delgamunkw (n 1), para 87. 
critical legal theory. While legal consciousness has a variety of definitions, ${ }^{4}$ in this paper it will refer to the ways in which individuals 'engage, avoid and resist' ${ }^{5}$ the law and legal meanings in everyday life.

Oral history is the process of recording oral testimonies with individuals in order to document their life history stories. Oral histories can be used as a means to recover neglected or silenced accounts of past experiences and guard against the appropriation of marginalised perspectives by dominant historical narratives. Oral sources are not found, but are rather generated through a dialogic, self-conscious exchange in which one person - the interviewer - asks questions to another person - generally referred to as the interviewee or narrator. These interviews allow the narrator sufficient time to tell their story in a way that focuses more on meanings than on facts. The content is grounded in reflections on the past and produces a verbal document that is available to the general public and researchers across disciplines. The method provides rich information about everyday life and insights into the mentalities of those whose perspectives are generally unavailable in the database of public social history. How is oral history able to enhance our understanding of legal consciousness? What makes this method different from other qualitative methods and what are its limitations?

This paper is organised as follows. The first section briefly reviews a number of methods traditionally used in sociological approaches to law, including surveys, ethnographies and in-depth interviews. I make the theoretical case for why oral history is an effective methodology for qualitative legal analysis, which in the second section is tested through an analysis of the oral histories of three Palestinian-Israeli women. I conclude with a brief discussion of the implications of using oral history as a methodology for critical legal studies.

\section{Situating the study of legal consciousness}

In order to explore the utility of oral history, we first need to trace the evolution of other methodological approaches towards the study of law and society. In particular, we will need to differentiate it from the in-depth interview, which is likely the closest alternative to oral history. ${ }^{6}$

The law and society movement attempts to explain legal phenomena within a complex social totality. Lawrence Friedman writes about the challenge of applying an empirical method to such a 'loose, wriggling, changing subject matter, shot through and through with normative ideas'. ${ }^{7}$ Indeed, the attempt to use purely quantitative methods to study law has been challenged from the very inception of the movement. Marx, Weber and Durkheim were fundamentally theoretical, attempting to locate law within the discourse of ideology and power.

4 Early studies of legal consciousness focused on levels of understanding of, knowledge of, and opinions about the law: A Sarat, 'Studying American Legal Culture: An Assessment of Survey Evidence' (1977) 10(3) Law and Society Review 427-88. Other studies of legal consciousness have used a constitutive approach in locating law in society. Merry, for example, defined legal consciousness as 'the ways people understand and use law', and K Bumiller approaches the subject through the lens of ideology: S E Merry, 'Concepts of Law and Justice among Working Class Americans' (1985) 9 Legal Studies Forum 59; K Bumiller, The Civil Rights Society (Johns Hopkins University Press 1988). This paper will focus primarily on Silbey and Ewick's approach to legal consciousness, in which they examine how ordinary people's understandings, awareness and conceptions of what constitutes 'law' or 'legality' essentially creates 'legality'. See P Ewick and S Silbey, The Common Place of Law: Stories from Everyday Life (University of Chicago Press 1998).

5 Ewick and Silbey (n 4).

6 S N Hesse-Biber and P Leavy, The Practice of Qualitative Research (Sage Publications 2011) 133.

7 L Friedman, 'The Law and Society Movement' (1986) 38 Stanford Law Review 763-80. 
While the usage of quantitative methods was popular throughout much of the twentieth century, the 1980s and 1990s witnessed a return to the movement's theoretical roots, in which a flood of critical and cultural legal theory emerged. The so-called interactionists followed this approach and based their sociological research on subjective accounts generated through ethnographical observation and unstructured, intensive interviews. ${ }^{8}$ They challenged the scientific value of remaining neutral or disinterested, arguing that dominant perspectives are not grounded in objective, observable reality, but rather in the interests of the dominant societal group. Foucault has contributed to this viewpoint in explaining the ways in which knowledge and power are linked.?

This qualitative turn in the law and society movement moved away from the sole examination of 'lawyer's law' towards a democratic framework in which law is experienced and understood by ordinary citizens. ${ }^{10}$ Researchers abandoned purely quantitative methods in favour of more qualitative analyses of social interactions. ${ }^{11}$

Since the 1960s, surveys have been conducted to assess why and when citizens turn to law. Early surveys generally found that individuals who are more educated and wealthy tend to resort to law as a means of dispute resolution. ${ }^{12}$ Although these studies described the differential use of law based on social position, the data nevertheless depicted a 'generally active and assertive citizenry' whose willingness to turn to the law reflected a widespread perception of the law as legitimate and sustainable. ${ }^{13}$ Susan Silbey critiques the survey method itself, revealing that often these studies measure popular agreement or disagreement, rather than conceptions of fairness, such as 'loyalty, compensatory treatment, or substantive equality'. ${ }^{14}$ These surveys, Silbey contends, are replete with leading questions that encourage conforming answers, discouraging responses that appear deviant or disloyal.

In ethnographical studies, data-gathering occurs within a setting referred to as a 'field' or a 'site', in which the researcher observes naturally occurring social interaction. ${ }^{15}$ Often, observation is accompanied by interviewing and/or participation in the activities of the subject that one is studying. Ethnographic studies of legal consciousness capture, in ways inaccessible to large surveys, the context and complexities of group behaviour and interaction using a variety of sources. Like oral history, it also has the potential to follow individuals over time. Studies such as that conducted by Donald Black ${ }^{16}$ confirm that all social groups experience grievances. However, whether or not people are able to name, blame and claim a grievance as a legal dispute ${ }^{17}$ is dependent on the 'social geometry' of everyone involved - such as whether the individuals are rich or poor and whether they are

8 Hesse-Biber and Leavy (n 6) 237.

9 M Foucault, The History of Sexuality, vol 1 (Vintage 1980).

10 See Merry (n 4). See also S Silbey, 'After Legal Consciousness' (2005) 1 Annual Review of Law and Social Sciences 323-68, 327.

11 See J Habermas, The Theory of Communicative Action, vol 2: Lifeworld and System (Beacon 1987).

12 See J Carlin et al, 'Civil Justice and the Poor: Issues for Sociological Research' (1966) 1(1) Law and Society Review 9-91; L Mayhew and A Reiss, 'The Social Organization of Legal Contracts' (1969) 34 American Sociological Review 309-18; and L H Goodman and S Sanborne, 'The Legal Needs of the Poor in New Jersey: A Preliminary Report' (National Social Science Law Center 1986).

13 Silbey (n 10).

14 Ibid 337.

15 Hesse-Biber and Leavy (n 6) 136.

16 D Black, The Behavior of Law (Academic Press 1976).

17 W Felstiner, R Abel and A Sarat identify three major steps - naming, blaming, claiming - that occur before a personal injury is able to turn into a dispute: W Felstiner et al, 'The Emergence and Transformation of Disputes: Naming, Blaming, Claiming' (1980) 15(3/4) Law and Society Review 631-54. 
intimates or strangers. ${ }^{18}$ Ethnographic studies tend to emphasise the cultural variability of disputing. ${ }^{19}$ Unlike traditional survey results, these studies generally depict ambivalent relationships to law and legal institutions, and populations that are rather reluctant to go to court unless their grievance seems intolerable or unavoidable.

Not only do ethnographic studies and surveys frequently generate contradictory outcomes, but they also contain different empirical values. The survey method seeks similarity through generalised statistical procedures that do not adequately depict cultural variability and often exclude phenomena that differentiate race, ethnicity and social class. Ethnographies, on the other hand, depict variability that cannot be generalised beyond the locale in which each study is conducted. ${ }^{20}$ The way in which research is conducted matters, as it often determines the outcome of the study.

\subsection{IN-DEPTH INTERVIEWS}

An in-depth interview is a structured conversation in which an interviewer asks detailed, pointed questions to a respondent. The method provides more qualitative information than data collected through surveys and, unlike ethnographies, it can be applied to assess more specific information about ideas, programmes or situations.

In order to examine how diverse and repetitive interactions of everyday life come together to form legal consciousness, Ewick and Silbey set out to conduct in-depth interviews with over 430 residents from four counties in New Jersey. ${ }^{21}$ They attempted to discover legality as it is recognised, resisted and reconstituted by a wide variety of ordinary people in everyday routine transactions.

Their interview involved 99 different probes that aimed to determine whether subjects had experienced specific events that could be described as 'legal', including instances that generated 'disputes, complaints and cases' or those legal events that did not necessarily culminate into an actual case. ${ }^{22}$ These probes included topics such as parking problems, noise complaints, vandalism, property disputes and work-related accidents. If the subject answered in the affirmative, the researchers would ask more direct questions on formal legal actions that were taken.

Silbey and Ewick recorded more than 5900 events, which could be grouped into three schemas. In one account, subjects located themselves 'before the law', viewing the legal system as something sacred and separate from the routines of daily life. In this account, people only invoked the law if it would benefit the needs of the general public. In another story, subjects were 'with the law', playing it like a game to further their own interests and values. In the third narrative, law was presented as 'arbitrary and capricious', in which certain interests were privileged over others. People revealed a sense of 'being up against the law', unable to 'either maintain the law's distance from their everyday lives or unable to play by its rules'. ${ }^{23}$

18 Black (n 16).

19 See S Macaulay, 'Non-contractual Relations in Business: A Preliminary Study' (1963) 28 American Sociological Review 1-23; D Engel, 'The Oven Bird's Song: Insiders, Outsiders, and Personal Injuries in an American Community'(1984) 18(4) Law and Society Review 551-82; C J Greenhouse, Praying for Justice: Faith, Order, and Community in an American Town (Cornell University Press 1986); B Cox and G Drever 'Some Recent Trends in Ethnographic Studies of Law' (1971) 5(3) Law and Society Review 407-16).

20 Silbey (n 10) 340.

21 Silbey and Ewick (n 4).

22 S Silbey, 'Everyday Life and the Constitution of Legality' in The Blackwell Companion to Sociology of Culture (1st edn, Blackwell 2005) 336.

23 Ibid 341. 
Legal consciousness emerges through this reciprocal process in which the meanings given by individuals to their world become 'patterned, stabilized and objectified' and then institutionalised to inform and constrain future meaning-making. ${ }^{24}$ Silbey and Ewick follow the Foucaultian idea of the pervasiveness of power and locate legality as 'all over'25 constituting power that is both institutional and embedded in everyday social practice. The following section will discuss whether oral history is able to capture legal consciousness in ways inaccessible to in-depth interviews.

\subsection{ORAL HISTORY}

How does oral history differ from other methodologies? Oral history interviews involve lengthy open conversations that are semi-structured or hardly structured at all. Open-ended questions and extended pauses within the interview allow the narrator time and space to be reflective and verbose.

Oral history interviews are far less structured than Silbey and Ewick's method of indepth interviewing. There are no probes or leading questions in an oral history interview. Rather, oral history demands a shift in methodology from 'information gathering, where the focus is on the right questions, to interaction, where the focus is on process, on the dynamic unfolding of the subject's viewpoint'. ${ }^{26}$ Oral history interviews generate information that is more qualitative and subjective than survey data. Unlike ethnographies, in which entire communities are narrated through the observations of the researcher, oral histories allow the subjects to speak for themselves.

Moreover, there is a life history component in oral history. Although some oral histories may focus on a specific event in an individual's life, the interview nevertheless contains a contextual element that allows the narrator to speak about his or her background and life story. I argue that the life history component of the oral history interview adds an intertemporal perspective to the study of legal consciousness. This approach allows the researcher to pay particular attention to structural constraints and enabling circumstances that determine the course of individual actions and decisions over time.

Through in-depth interviewing, Ewick and Silbey demonstrate an approach in which numerous instances of everyday legal interactions culminate to form a collective understanding of the law. However, they fail to account for how cultural practice works. They emphasise that the primary means of social action and cultural practice are stories, 'individual narratives that circulate and become the basis of collective action'. ${ }^{27}$ But, as Mezey asks: 'How and when does the circulation of narrative come to form a pattern that is more broadly recognizable as cultural practice?"28 How do individual narratives become the basis of collective action and understanding? What are the mechanisms of transmission and inscription?

As Jean Piaget argues: 'By considering only adults we perceive only mechanisms which are already formed, whereas by following childhood development, we reach to the formation of those mechanisms, and formation alone is explicative. ${ }^{29}$ Through the life

24 Silbey (n 22) 336.

25 A Sarat, “'The Law is All Over”: Power, Resistance and the Legal Consciousness of the Welfare Poor' (1990) 2 Yale Journal of Law and Humanities 343-79.

26 K Anderson and D Jack, 'Learning to Listen: Interview Techniques and Analyses' in S Gluck and P Daphne (eds), Women's Words: The Feminist Practice of Oral History (1st edn, Routledge 1991)) 23.

27 N Mezey, 'Out of the Ordinary: Law, Power, Culture and the Commonplace' (2001) 26 Law and Society Inquiry , 145-67, 161.

28 Ibid 161.

29 J Piaget, Epistémologie des sciences de l'homme, Chantal Kourilsky Augeven (trans) (Gallimard 1972) 139. 
history component, oral history adds an intertemporal analysis to how narratives circulate, what motivates people to engage in social or legal action, and the formation of mental attitudes that give meaning to such actions. As a biographical documentation of 'a long period of a person's life or even their entire life', ${ }^{30}$ oral history portrays the forces that influence the formation of social consciousness, including the narratives that one hears and internalises from parents and grandparents; the transmission of social values through the family and local community; the observation of adult interaction; initial contacts with the outside world, particularly in the school context; and through specific sites of mass initiation and inscription, what Mezey terms the 'common places of law': 'the news, television shows, movies, novels, comics, high school civics courses'. 31 Personal experiences, historical circumstances and cultural frameworks further shape these sites of consciousness formation. Oral history is a unique methodology in that it allows us to view the construction of culture in terms of processes rather than structures, and social institutions as the product of human interaction over time. ${ }^{32}$

In order to assess the functionality of oral history as a tool of qualitative legal analysis, I will use a collection of oral history interviews I conducted as part of an independent project in Israel and the West Bank in 2011. I interviewed 13 Jewish-Israeli and 14 Palestinian-Israeli women across Israel, and four non-Israeli-Palestinian women in the West Bank. The initial purpose of my study was to understand how women's political and feminist consciousness emerges within the context of the Israeli-Palestinian conflict and develops over time.

The format of my interviews was very flexible and conversational, allowing me to ask for clarification, to gauge the subjective meaning behind the narrator's experiences, and to go beyond 'conventional, expected answers to the woman's personal construction of her own experience'. ${ }^{33}$ I loosely structured each session chronologically, beginning by asking the narrator about her childhood and moving towards more emotionally or politically charged themes. Fabula, chronological order, and sujet, the way the facts were arranged by the narrator, were both important factors in the telling of the life history. ${ }^{34}$

\section{Case study: Palestinian-Israeli women}

Israel defines itself as both a Jewish and a democratic state. Although Israel's legal system is based on Western legal culture, promoting values that aim to be 'secular, liberal and rational', 35 the legal system also contains aspects of religious law inherited from the Ottoman tradition. Jewish, Muslim, Christian and Druze courts deal primarily with questions of personal status, including marriage and divorce. The Basic Laws substitute a formal constitution and aim to protect human dignity and liberty.

The democratic aspect of the state guarantees free elections, majority rule, an independent judiciary, separation of powers and human rights. ${ }^{36}$ Yet the precedent on which the current system is based reflects an inherently unequal foundation. Upon gaining its independence in 1948, Israel enacted the Law of Return, guaranteeing Jews the right to

30 Mezey (n 27) 152.

31 Ibid 162.

32 S N Hesse-Biber and P Leavy, The Practice of Qualitative Research (Sage Publications 2006) 238.

33 Anderson and Jack (n 26) 23.

34 S Snider, 'Oral History: Stories and their Variations' (lecture at New York University 2010).

35 A Barak, 'Some Reflections on the Israeli Legal System and its Judiciary' (2002) 6(1) Electronic Journal of Comparative Law <www.ejcl.org/61/art61-1.html>.

36 Ibid. 
settle in Israel and gain citizenship. The Zionist movement, ${ }^{37}$ viewing Judaism as a combination of 'nationality, ethnicity and religion' demanded exclusive right to the land of Israel as the sole homeland of the ethnic Jewish nation. ${ }^{38}$ Oren Yiftachel argues that Israel is an 'ethnocracy', suggesting that it is neither democratic nor authoritarian, with rights depending on one's ethnic origin and geographic location. ${ }^{39}$

For most Palestinians, the establishment of the state of Israel in 1948 is known in Arabic as the Nakba ('disaster' or 'catastrophe'), as approximately 720,000 Palestinian Arabs left, fled, or were expelled from their homes. ${ }^{40}$ Roughly 65 to 85 per cent of Palestinians living within the borders of Israel were forced into permanent exile with no right of return, while another 25 per cent became internal refugees in Israel. The Palestinians that remained within Israel's borders became de facto citizens of the new state and now comprise 20.4 per cent of the population.

This minority occupies an ambivalent position in the Jewish state as its members are perceived as internal enemies, a population that needs to be controlled and contained. Although the state guarantees basic human rights to the Arab citizens of Israel, structural discrimination towards Arabs seriously prohibits the full realisation of civil rights. Institutionalised discrimination is practised against Palestinian citizens in all areas, including land dispossession and allocation, education, economics, language, housing, culture and political participation.

Cultural and traditional practices that inhibit the realisation of human rights occur within groups as well, creating an additional discriminatory system that contributes to layers of inequality'41 experienced by Palestinian women in Israel. Within the Arab communities of Israel, patriarchal clans known as hamula have retained much of their power and political significance. ${ }^{42}$ The state has consistently supported these clans as a means to relinquish 'all matters of personal status to the different religious courts' and to support 'the normative authority of local notables over young men, and more particularly over women'. ${ }^{43}$ Palestinian women are thus located in what Robert W Connell has described as 'gender regimes', meaning power relations and hierarchies within all major social institutions, particularly within families, workplaces, state bureaucracies and other collectivities. ${ }^{44}$ These gendered regimes complement and reinforce one another to produce multiple layers of law and legality.

Badi Hasisi finds a legal culture of mistrust and cynicism amongst the PalestinianIsraelis. ${ }^{45} \mathrm{He}$ uses quantitative survey methods to find an extremely low level of reported crimes in the Arab communities in the northern district of Israel and a high level of

37 The aim of the Zionist movement was to create for the Jewish people a nationalist home in Palestine secured by public law. See J L Gelvin, The Israel-Palestine Conflict: One Hundred Years of War (CUP 2007) 52.

38 A Ghanem and S Ozacky-Lazar, 'The Status of the Palestinians in Israel in an Era of Peace' (2002) 9(102) Israel Affairs 268.

39 O Yiftachel, “Ethnocracy” and its Discontents: Minorities, Protests, and the Israeli Polity” (2000) 26(4) Critical Inquiry 725-56.

40 Gelvin (n 37) 135.

41 T Makkonen, Multiple, Compound and Intersectional Discrimination: Bringing the Experiences of the Most Marginalized to the Fore' (Institute for Human Rights 2002) 17.

42 A Sa'ar, 'Contradictory Location: Assessing the Position of Palestinian Women Citizens of Israel' (2007) 3(3) Journal of Middle East Women's Studies 49.

43 Ibid 50.

44 R W Connell, 'New Directions in Gender Theory, Masculinity Research, and Gender Politics' (1996) 61(3-4) Ethnos 157-76.

45 B. Hasisi, 'Criminology: Police, Politics, and Culture in a Deeply Divided Society' (2008) 98(3) Journal of Criminal Law and Criminology 1119-45. 
distrust in the police force. These findings can be attributed to 'political marginalization, feelings of discrimination [and] regime delegitimation among the Arab minority in Israel'. ${ }^{46}$ Feelings of exclusion and autonomy in the Arab community are furthered by the neglect of the Israeli police force, which views the Arab minority as relatively unthreatening to the majority community.

\subsection{THE DEVELOPMENT OF LEGAL CONSCIOUSNESS}

What can oral history tell us about the ways in which Palestinian citizens resist, manipulate, or acquiesce to law's power? This section will explore the utility of oral history as a tool of intertemporal legal analysis by presenting the stories of three Palestinian-Israeli women as they relate their own processes of identity-formation.

\subsubsection{Samia}

Consider the story told by Samia, ${ }^{47}$ a 40 -year old Palestinian citizen of Israel who grew up in the city of Nazareth, the largest city in the northern district of Israel. A researcher and advocate, her doctoral research explores the importance of memory as a political and historical tool in nation-building, focusing specifically on the diverse experiences of displaced Palestinian women in the so-called 'Nakba generation'. ${ }^{48}$ During the interview, Samia spoke extensively about her own family history upon the establishment of the state of Israel in 1948:

The Zionist forces came to Nazareth on 16 July 1948, and my father was two days old. My grandfather, he used to tell me that the Zionist forces put the citizens of Nazareth from our neighborhood close to the mosque, in trucks, in order to move them to the Lebanese border. And my grandfather and grandmum, they used to lie in front of the truck's wheels. They did not want the Nazareth population to become refugees in Lebanon. There are a lot of stories ... 49

During the interview, she described Amendment No 40 to the Budgets Foundation Law, 50 also known as the 'Nakba Law', as 'fascist' and 'racist'. The law authorises the Finance Minister to reduce state-funding or support to any institution if it holds an activity that commemorates 'Israel's Independence Day or the day on which the state was established as a day of mourning. ${ }^{51}$ Samia views the law as an infringement on free speech, representing a legal system that does not allow Arab citizens to preserve their history and culture.

She asks: 'How can I bring my child to grow up in this sick unhealthy society? I can't understand how a state which claims itself as a democratic state can have this law just to remove memories. 52

The oral history interview represented a space for Samia to trace the development of her social, political and legal consciousness and re-appropriate her historical narrative. Raised in a communist family, she remembers policemen coming to her home to arrest her father and uncle for their politically subversive activities. Her earliest memory of political

46 B Hasisi, 'Policing Minorities in a Deeply Divided Society' in D Avnon and Y Benziman (eds), Plurality and Citizenship in Israel: Moving beyond the Jewish/Palestinian Divide (1st edn, Routledge 2010) 155.

47 The names of these women have been changed to protect their identity; the names of locations are real.

48 The Nakba Generation refers to those who were dispossessed or displaced following the creation of the state of Israel.

49 Samia, Personal Interview, 18 May 2011.

50 Budget Foundations Law (Amendment No 40) (5771-2011), passed by Knesset on 23 March 2011.

51 Ibid.

52 Samia, Personal Interview. 
activism involved a demonstration against the Sabra and Shatila massacres ${ }^{53}$ during the Lebanon War in 1982: 'I was afraid. I remember that my grandmother was holding my hand all the time. We were running and escaping and trying to avoid the tear gas. It was fear. It was really fear.' 54

Samia grew up in a family that was up 'against the law'. Her earliest interactions with legal authorities involved fear, arrests and tear gas. Samia goes on to describe how her family values further shaped her perceptions:

Growing up in Nazareth, we didn't learn anything about the Revolutions, we didn't know about the Arab Revolutions in 1936.55 We didn't read Mahmoud Darwish $^{56}$ in our curriculum, we didn't know Tawfiq Ziad. ${ }^{57}$ So you know, we didn't know about our history . . . I learned from my family and other political activities. 58

Samia was nurtured by a political consciousness that made her feel different from her classmates and neighbours. Values within her family ceased to be taken for granted and instead became defining characteristics because they were perceived by the outside world as factors of differentiation. Through the course of the oral history interview, Samia explored the development of her awareness as a marginal minority within Israeli society. She emphasises moments of conflict as determining the emergence of a legal consciousness that is 'up against the law'.

The intertemporal perspective revealed by this oral history interview echoes sociologist June Tapp's notion of socialisation, in which individuals come to abide by legal norms through successive phases of learning - first by conformity and later through moral internalisation. ${ }^{59} \mathrm{I}$ argue that Tapp's concept of socialisation privileges the notion of obedience or compliance with law, thus reducing legal discipline to written, known laws. Conformity to written law does not emerge as a salient element within the narrative told by Samia. Contrarily, she defines herself by acts of refusal and consistently refers to structural forces such as gender, ethnicity and political affiliation as playing a direct role in shaping her experiences and everyday interactions.

Samia's political and social consciousness is closely tied to her understanding of law. The Israeli legal system, like most legal systems, reflects certain ethnic and religious interests. Legal norms are an extension of social norms, provided that social norms enjoy 'authoritative validity'. ${ }^{60}$ The line between social and legal consciousness is barely distinguishable. Therefore, when examining the development of legal consciousness through the use of oral histories, legality should be defined broadly to encompass political and cultural forms of authority that define and pattern social life. ${ }^{61}$

53 On 17 September 1982, Israeli-backed Lebanese Phalangist militiamen slaughtered at least 800 civilians in the Sabra and Shatila Palestinian refugee camps in West Beirut. 'Flashback: Sabra and Shatila Massacres' (BBC News 24 January 2002) <http://news.bbc.co.uk/2/hi/middle_east/1779713.stm> accessed 6 February 2013.

54 Samia, Personal Interview.

55 The Arab Revolt was a Palestinian rebellion against the British Mandate and Jewish immigration (1936-1939).

56 Mahmoud Darwish was a nationalistic Palestinian poet who wrote about dispossession and exile (1941-2008):

B Ze-ev, Remembering Palestine in 1948: Beyond National Narratives (Cambridge University Press 2011) 25.

57 Tawfiq Ziad was a Palestinian politician and poet (7 May 1929-5 July 1994). Ibid 218.

58 Samia, Personal Interview.

59 J L Tapp, 'Socialization, the Law, and Society: Reflections' (1971) 27(2) Journal of Social Issues 1-16.

60 Ibid $4-5$.

61 See W H Sewell, 'A Theory of Structure' (1992) 98 American Journal of Sociology 1-29. 


\subsubsection{Fatma}

Fatma is a practising lawyer from Lod, a so-called 'mixed city' of both Jewish and Arab inhabitants. Unlike Samia, Fatma grew up with many silences in her historical narrative:

My grandmother never talked about [the Nakba], never ever. And neither did my grandfather. The historical story that we learned in school talks about the Jewish narrative only, it doesn't bring in the Palestinian narrative. We never had two sides of the story. ${ }^{62}$

She attributes her family's reluctance 'to touch politics' to the military laws ${ }^{63}$ that governed the life of Palestinian-Israelis from 1949-1966:

The laws and system in Israel were very much military, and people didn't have much freedom, of speech, of movement, of . . . you know, I hear stories of Palestinians who didn't even want to talk about politics over the phone because they were afraid that someone was following them, [or] they couldn't talk about it without getting hurt, or taken to jail or something like that. ${ }^{64}$

Fatma was never involved with system-challenging behaviour, seeing it as an activity that could harm her chances to develop a legal career in the state or the ministry. She occupies an ambivalent position in wanting to work within a system that regards her as an unequal citizen: 'I think it's a psychology of being a minority, on the one hand [we are] very much oppressed, but on the other hand, [we want] to be, [we want] to live the life ... '65

Fatma engages with the law as it relates to women's rights. She explains: 'I was never actually very involved with politics, even today. I'm in feminism, first and foremost.' ${ }^{66}$ She worked at the Ministry of Law's Legal Aid Department in Jerusalem before becoming a women's rights lawyer at Kayan, advocating on behalf of Palestinian women in cases that involve sexual harassment in the workplace, domestic violence and discrimination.

She describes the development of her feminist consciousness and her feelings of inferiority within her family:

The different limits and standards that my parents set for us, for [my brother] as a boy and me as a girl, were very clear and very different. I did not live with it in peace, I did not just accept it as my reality ... I believe that feminism really did help me in that sense. It did give me a lot of power to abandon barriers that society had imposed upon me as a woman. For a long time I didn't think about it in terms of feminism, but rather in terms of equality and personal need. ${ }^{67}$

Fatma chose to study law as something that would empower her as a woman: 'T'm good at talking and fighting, fighting for rights. It was always clear to me that I would study law. 68

Her attitude towards the law and her legal profession is filled with both hope and frustration:

I think my work is changing the system as a whole. I mean, I think I have to believe in order for me to keep up the work. I believe it does bring changes, but in very small tiny steps. As a minority, my main challenge is the issue of

62 Fatma, Personal Interview, 11 April 2011.

63 Upon the establishment of the state of Israel, Arabs remaining within the border were subject to harsh military laws, including curfews, administrative detentions and expulsions.

64 Fatma, Personal Interview.

65 Ibid.

66 Ibid.

67 Ibid.

68 Ibid. 
legitimacy, being a lawyer that is reliable, that people can come to and not think,

'Well, she's an Arab lawyer so she's probably not good enough . . .'69

Fatma locates her story within the ambivalent legal culture of Palestinian citizens of Israel. In some ways she is 'before the law', invoking a conception of how law should be. Her feminist identity has allowed her to internalise liberal notions of equality, human rights and citizenship. She is also 'with the law', using the rules of law to advance women's rights. Yet in other ways Fatma is 'against the law', highlighting the lack of equality within the current legal system and the difficulties that she faces as a minority woman.

\subsubsection{Lana}

Many narrators in this oral history collection made no explicit references to official state institutions, and law was seemingly absent in their accounts. Indeed, to know the uses of law, "we need to know not only how and by whom the law is used, but also when and by whom it is not used'. ${ }^{70}$ Lana, a 26-year old Bedouin woman from a village outside Nazareth, defines her personal struggle as existing within the power relations of her family and community.

She was 21 when she made her first posting on an online forum for Palestinian lesbian women. It wasn't until she was 19 that she even knew the Arabic word for lesbian, 'mithlya'. Finding the online forum allowed Lana to feel that she was not alone. Yet when her father found out she was using the internet, he mistakenly assumed she was talking to boys - and he beat her.

Lana realised that the only way to leave the Bedouin village was to get married. She reflects on the irony:

Ok, and this is one of my problems! [laughs] I don't want to get married. I looked for a gay guy that was in the same situation, you know, like his family wants him to get married. I found a guy . . . he's living in the US. He's living alone, he's gay, and he doesn't want his family to know about it. His family is also trying to push him to get married. He's Arab and he's Palestinian. So we made a deal, we can get married, and I'll [leave the village]. This is what happened. ${ }^{71}$

Lana thus chose the institution of marriage as a means to escape the authority of her family. Silbey and Ewick would perhaps define this act of resistance as a 'masquerade', in which an individual plays with expected roles. ${ }^{72}$ Lana manipulates traditional expectations, marrying a suitable Palestinian man in order to live independently of her family. Yet her life is still filled with challenges as she attempts to maintain the masquerade: 'I'm in a dilemma. I was in a relationship for two years. My wedding was the same day as the anniversary with my girlfriend! I want to stay with her, but at the same time I want my freedom. ${ }^{73}$

She continues to visit her girlfriend in Haifa without her family's knowledge:

Aswat $^{74}$ is my home when I come here. But I can't go out. I can only go to the few places where no one knows me. My family doesn't know I'm here. When I'm

69 Fatma, Personal Interview.

70 S Silbey and P Ewick, 'Conformity, Contestation, and Resistance’ (1992) New England Law Review 737 (my emphasis).

71 Lana, Personal Interview, 24 March 2011.

72 S Silbey and P Ewick 'Narrating Social Structures: Stories of Resistance to Legal Authority' (2003) 108(6) American Journal of Sociology 1350-1.

73 Lana, Personal Interview.

74 Aswat is the Forum for Palestinian Lesbians based in Haifa, Israel < www.aswatgroup.org/>. 
walking on the street, I don't take buses. I always have glasses on, I dye my hair, I cover my face with my scarf. ${ }^{75}$

Lana does not use law to bring a case against the discrimination, violence and the threat of violence prevalent in her home. Rather, she relies on her own ability to contest cultural authority that governs her life. In order to make a claim about Lana's legal consciousness, we would need to examine the legal culture existing within Bedouin society. ${ }^{76}$ Like most Palestinian lesbians, Lana balances her desire to live freely and to demand acceptance from her community, with the need for protection and safety. Perhaps she views the legal system as an option that does not provide the safety and confidentiality she desires; or perhaps as a member of the Palestinian minority she perceives the official state legal system with distrust. She chooses instead to use the forum of Aswat to fight for the collective rights of Palestinian lesbians, rather than bring forth a legal case of her own. Lana continues to use the online forum to share her story with others, strengthening the voices of other Palestinian lesbians and nudging society towards equality

\section{Overcoming limitations: a combined method}

An oral history analysis can greatly contribute to the study of legal consciousness as process, paralleling the development of social and political consciousness. Its strength lies in its richness and depth and in its methodological approach that allows participants to structure the world as they see it, rather than as the analyst sees it. ${ }^{77}$

However, oral history is limited in that it documents rather subjective accounts, informed by an individual's fallible memory and psychological state. The use of grounded theory to generate theories of legal consciousness can further lead to interpretive conflict, in which tensions arise between the researcher's authority over interpretation and the subject's own interpretation. An oral history methodology does not preclude the danger of appropriation or exploitation of people's stories by researchers and practitioners.

Despite these shaky grounds, oral history allows us to glimpse into the inner world of the individual, as we attend to the logic of narrative, the processes of attitude formation, and moments of cognitive dissonance in which the narrator attempts to reconcile contradictions into a salient belief system. Oral historians value contradictions because these inaccuracies 'provide an important avenue of insight into a respondent's state of mind [and memory]'. ${ }^{78}$ There are no lies in oral history, as all statements are meaningful and relevant to the speaker. ${ }^{79}$

Psychologist Dana Jack advises oral historians to listen to the narrator's 'moral language' and 'mega-statements', and the ways in which major anecdotes are strung together in order to understand the assumptions and beliefs that guide a subject's logical interpretation of her experience. ${ }^{80}$ The process of storytelling itself includes moments of 'realization, awareness, and, ideally, education and empowerment' 81 that cannot be found in any other method of

75 Lana, Personal Interview.

76 See A R Queder, 'Permission to Rebel: Arab Bedouin Women's Changing Negotiation of Social Roles' (2007) 33(2) Feminist Studies 164; and C Bailey, Bedouin Law from Sinai and the Negev (Yale University Press 2009).

77 M Rank, 'The Blending of Qualitative and Quantitative Methods in Understanding Childbearing among Welfare Recipients' in S N Hesse-Biber and P Leavy (eds.), Approaches to Qualitative Research (Oxford University Press 2003) 81-96.

78 D Patai, 'Whose Truth? Iconicity and Accuracy in the World of Testimonial Literature' in A Arturo (ed), The Rigoberta Menchu Controversy (1st edn, University of Minnesota Press 2001) 270-86.

79 G Lovell and C Lutz, 'The Primacy of Larger Truths' (2001) in Arturo (n 78) 175.

80 Anderson and Jack (n 26).

81 Hesse-Biber and Leavy (n 6) 150. 
sociological analyses. The oral history narratives of Samia, Fatma and Lana reveal rich data on the meta-narratives of identity formation.

Yet, these narratives are nevertheless lacking in their ability to trace direct causation and isolate variables that are specifically legal. In order to pinpoint the law more directly, I suggest a combined methodology of in-depth interviewing and oral history. In-depth interviewing reveals minute incidents of legal interaction that may not emerge in the course of an oral history interview. Silbey's study relates numerous incidents related to the law, conjuring images of 'parking tickets, age restrictions for drinking, criminal enterprise, voting regulations, and taxes'. ${ }^{82}$ Many of those interviewed appeared in minor criminal courts, others in civil courts for major cases, 'divorce proceedings, small claims, or as jurors'. ${ }^{83}$ Conversely, oral history narrators emphasise legal matters that are particularly personal or political, omitting everyday legal incidents unless they play a defining role in the way the narrator has come to perceive the world. In-depth interviewing sheds light on micro-level legal interactions that constitute legal consciousness in ways inaccessible to oral history alone.

I conceive of a combined method as follows. The researcher would begin each interview with an oral history component, allowing the narrator an open space to trace his or her childhood, adolescence and adulthood. The interview would then move into an in-depth interview, in which the researcher would pose a set of questions related to individual interaction with the law, much in line with the method of Silbey and Ewick.

Sociologists studying legal consciousness could benefit by emulating the comprehensive research methodologies used by oral historians. In turn, the practice of legal oral historians could be enhanced by utilising in-depth interviews to obtain more specifically legal information.

\subsection{REASSERTING THE POWER OF NARRATIVE}

The legal system uses 'filtering concepts' 84 such as relevant evidence to limit what facts a court considers. The legal concept of 'relevance' empowers a court to approve or disapprove certain narrative elements of a party's story. By considering oral history as relevant evidence in the case of Delgamunkw v British Columbia, ${ }^{85}$ the Canadian Supreme Court legitimised aboriginal knowledge. Oral history allows for a totality of collective truth to emerge through the court proceedings. Unlike interviews, which are often replete with leading questions, oral history allows subjects to claim ownership and take control of their own stories. An oral history methodology can expose the gap between law as it is imagined, and law as it is experienced by individuals or groups. As such, the discipline can contribute to critical legal theory as a means to expose the realities of marginalisation under the promise of formal equality.

When analysed as a collection of narratives from a broad array of individuals, narrative studies can reveal something systematic about citizens' structural relationship to legality. The reflections that emerge during the oral histories of the Palestinian-Israeli women, for example, echo Hasisi's finding of a legal culture of cynicism and doubt amongst the Palestinian-Israeli community. ${ }^{86}$ The oral histories presented in this paper suggest that, while there are elements of both 'before' and 'with the law', Palestinian-Israeli women most

82 Silbey and Ewick (n 70) 736.

83 Ibid.

84 M Barnes, 'Black Women's Stories and the Criminal Law' (2006) 39(941) University of California, Davis 941-90, 944 n 5.

85 Delgamunkw (n 1).

86 Hasisi (n 45). 
often display a unique form of 'avoiding and/or resisting the law' legal consciousness. In many cases, this attitude is coupled with deep ambivalence. For example, Fatma works within an inherently unequal system in an attempt to improve the lives of minority women. These narratives provide new vocabulary, images and metaphors for conceptualising inequality in Israel and present opportunities for political mobilisation and legal re-appropriation.

Silbey and Ewick's study on legal consciousness is purely descriptive, drawing attention to the social construction of law from an individualist perspective. There is a lack of engagement with the effects of structural constraints based on social characteristics, which could impact individual legal consciousness. ${ }^{87}$ The researchers attempt to address this issue by presenting the story of Millie Simpson - a young black woman who was stigmatised under the law. However, the example is nevertheless insufficient in describing the development and the source of Millie's legal consciousness. According to Ewick and Silbey, consciousness is 'the participation in the production of structures'. ${ }^{8}$ Yet Simpson, constrained by intersectional forms of marginalisation, does not have the same ability to participate in the construction of social structures and is rendered largely invisible within the court. It wasn't until a private attorney retold her story at a third proceeding that the court found Millie innocent. Even then, she was seemingly absent from the transaction. Her experiences "paint a picture of her mostly being "acted upon" without her input or participation'. ${ }^{89}$ An oral history analysis could greatly contribute to the study of critical legal theory, exposing hierarchies of dominance and essentialism that negate the presence of minority women such as Millie under the law. As Angela Harris and Leslie Espinoza explain:

Arguably, the most significant impact of critical theory has been the reformation of legal analytical practices through the use of stories. Outsider tales provide an opportunity to breach the limits of language in describing oppression. ${ }^{90}$

The oral histories of Palestinian-Israeli women extend our understanding of individual legal consciousness into a critique of law and legal processes as a whole, drawing attention to relationships of power and resistance in everyday life.

Silbey and Ewick's concept of legal consciousness is rather individualistic, implying a process that occurs within a single mind. Oral history is able to offer an analysis of legal consciousness that does end with the individual. As a feminist-informed research method, oral history alerts us to the silences and absences in familiar institutions, such as the legal system, and focuses on marginalised and excluded peoples' collective experiences. The discipline offers 'a unique and provocative means of gathering information central to understanding women's lives and viewpoints', ${ }^{11}$ which have more often than not been excluded in traditional legal discourse. An analysis of women's subordination, and, in particular, the experiences of minority women, is tied to a normative goal of fostering effective reform and guarding against appropriation. ${ }^{92}$

Oral history could thus be used to develop effective anti-discrimination laws. The legal system of Israel is based on a liberal individualist theory, which defines the task of anti-

87 See S F Hirsch, 'Subjects in Spite of Themselves: Legal Consciousness among Working-class New Englanders (1993) 17(4) Law and Social Inquiry 839-57.

88 Silbey and Ewick (n 4) 24.

89 Barnes (n 84) 979.

90 L Espinoza and A Harris, 'Embracing the Tar-Baby' (1997) 85(5) California Law Review 544.

91 G Etter-Lewis, 'Black Women's Life Stories: Reclaiming Self in Narrative Texts' in Gluck and Daphne (n 26) 43.

92 L Gordon, 'The Struggle for Reproductive Freedom' in Z R Eisenstein (ed), Capitalist Patriarchy and the Case for Socialist Feminism (Monthly Review Press 1979). 
discrimination law as passive and non-substantive. Such a blind approach to ethnic, religious, or gender differences seeks equality, yet 'does not embrace a purposeful classification on the basis of proscribed group affiliation'. ${ }^{93}$ Anti-discrimination cases in Israel are dealt with on a case-by-case basis, precluding the potential for transformative and substantive equality. For example, the Supreme Court case of Kadaan v Israel's Land Administration ${ }^{94}$ in 2000 was the first case to maintain the principle of equality for Palestinian citizens of Israel. However, while upholding an Arab family's right to buy a house in a predominately Jewish neighbourhood, the court ultimately failed to address any historical formal and material ethnic discrimination against Palestinian citizens in land and housing. ${ }^{95}$

Further legal research through oral histories could also be used to explore a feminist critique of rights, deepening a gendered analysis of topics such as competing rights, direct and indirect discrimination, intersectional forms of discrimination, and conceptions of national identity and citizenship. For example, many of the women interviewed spoke about marriage, divorce, and child custody - legal matters that occurred within the so-called 'private' sphere yet are legislated by official 'public' institutions. By appropriating the private concerns of women into the pool of public social knowledge and history, oral histories could challenge the traditional legal divide between the public and the private spheres.

As a tool of critical legal theory and practice, oral history invokes an approach to equality that takes into account collective legal needs based on historical disadvantage. Oral history can be used to 'link micro- and macro phenomena and personal life experiences to broader historical circumstances. ${ }^{96}$ The narrative collection of Palestinian-Israeli women is a normative assertion of outsider identities, and, if taken seriously, can effectively challenge a legal system fraught with systematic exclusion.

\section{Conclusion}

Scholarly literature on Palestinian women in Israel is generally focused on either oppression or empowerment. ${ }^{97}$ Accounts of oral history complicate this polarity by drawing attention to the structural tensions between the various legal regimes that preside over the lives of Palestinian women citizens of Israel, which are pertinent to both the oppressive and the resistive aspects of the women's lives. For example, Lana's process of decision-making and personal transformation is located within a web of oppression and opportunity, of finding a crack in the system and using resources at hand to expose power. The act of storytelling itself transforms each momentary transaction into a historic event. ${ }^{98}$

Furthermore, a combined methodology of oral history and in-depth interviewing would greatly enrich our understanding of legal consciousness and could inform antidiscrimination laws. As an intertemporal tool of analysis, oral history can be used as a study of process in the formation of legal understandings and actions. The biographical element of an oral history interview points to moments of attitudinal shifts caused by particular life experiences and changing historical circumstances. If one is exploring how individuals engage with, avoid and/or resist the law and legal structures, oral history allows one to not

93 Y Jabareen, 'Critical Reflection on Law, Equal Citizenship and Transformation' in D Avnon and Y Benziman (eds), Plurality and Citizenship in Israel: Moving beyond the Jewish/Palestinian Civil Divide (1st edn Routledge 2010) 70 .

94 HC 6698/95 Kadaan v Israel Land Administration, 54(1) PD 258 (5760/61-2000).

95 Jabareen (n 93) 76.

96 Hesse-Biber and Leavy (n 6) 153.

97 Sa'ar (n 42).

98 Silbey and Ewick (n 72). 
only understand what the subject is currently experiencing and her perspective on that, but the process that led her there.

Through the oral histories of three Palestinian-Israeli women, I have demonstrated the ways in which oral history offers a contextualised approach to multiple grounds of discrimination, while drawing attention to moments of resistance and agency. As an intertemporal technique, the life history component of the oral history interview traces the development of legal consciousness over time. Oral history allows us to understand the cultural, social and historical environments of Samia, Fatma and Lana. As demonstrated through the case of Delgamunkw v British Columbia, the discipline gives weight to larger narratives of collective historical experiences. As an assertion of outsider identities and narratives, oral histories can be used as a powerful advocacy tool in effective legal reform. 